\title{
La gran pantalla en guerra: Segunda guerra mundial y noticiarios cinematográficos Luce (1940-1945)
}

\author{
Carlota CORONADO RUIZ \\ carlotacoronado@gmail.com \\ Universidad Complutense de Madrid
}

Recibido: 20/09/2015

Aceptado: 21/10/2015

\section{RESUMEN}

En la Segunda Guerra Mundial la propaganda se convirtió en un campo de batalla más: en el caso de Italia era necesario crear en una opinión pública favorable a la guerra sin crear alarmismos. Para ello se utilizó uno de los instrumentos más eficaces para la propaganda del fascismo: el noticiario cinematográfico Luce. Este artículo analiza la representación que los noticiarios producidos desde 1940 hasta 1945 ofrecen de la Segunda Guerra Mundial. Se apuntan los temas más recurrentes, las características de las noticias sobre la guerra y se señalan las grandes ausencias debidas a la censura del Régimen de Mussolini.

Palabras clave: Segunda Guerra Mundial, Italia, propaganda, cine, noticiarios.

\section{The Big Screen at War: Second World War and Luce Newsreels (1940-1945)}

\begin{abstract}
During the Second World War propaganda became another battlefield. In Italy's case, a favorable public opinion towards the war became a necessity, without creating any unnecessary alarm. For that purpose, one of the most effective instruments in fascist propaganda was used: The Luce cinema news bulletin. This article analyses the portraying of WW2 in newsreels from 1940 to 1945. The most recurring themes are mentioned, along with the new's coverage of wars facts and the great absences due to Mussolini's fascist regime are duly noted.

Keywords: Second World War, Italy, Propaganda, Cinema, Newsreels.
\end{abstract}

\section{Referencia normalizada}

Coronado Ruiz, C. (2015). "La gran pantalla en guerra: Segunda guerra mundial y noticiarios cinematográficos Luce (1940-1945)”. Documentación de las Ciencias de la Información, Vol. 38. Páginas 285300. 


\section{INTRODUCCIÓN}

El archivo cinematográfico del Instituto Luce es posiblemente uno de los fondos documentales más ricos sobre cine de no ficción. Conserva la memoria de Italia y de parte de Europa de más de medio siglo - 1928-1990 -. Sus documentos históricos han sido difundidos en Italia a través de programas televisivos y de la realización de documentales. Con estos fondos se han llevado a cabo también, en los últimos años, investigaciones relacionadas con la imagen y la propaganda del fascismo. Los temas más estudiados en los noticiarios italianos del Archivo Luce son los referidos a la política fascista, a su líder y a determinados aspectos de la Segunda Guerra Mundial. Estas investigaciones ponen de manifiesto el interés y la importancia que, entre los sectores académicos, se ha conferido recientemente a esta fuente documental.

Los noticiarios cinematográficos procedentes del Archivo Luce constituyen las fuentes primarias que han servido de herramienta fundamental de trabajo para esta investigación. El patrimonio de Luce está compuesto actualmente por 12.000 noticiarios cinematográficos, 4.700 documentales y otros tipos de películas que incluyen desde filmes de los orígenes del cine a la documentación de los eventos y de la vida social de las últimas décadas. Se conservan, además, un millón de metros de descartes, es decir, película filmada pero no montada, que componen el "repertorio" Incom y Luce. A este material hay que añadir los aproximadamente tres millones de fotografías realizadas por Luce o de procedencia externa, en fase de catalogación y digitalización.

Además de la base de datos consultable en la sede de Cinecittà en Roma, el Archivio Luce ha puesto a disposición del público y de los investigadores su material audiovisual a través de Internet. En este archivo se conservan dieciocho colecciones de noticiarios. Cubren un arco temporal que va desde 1927 hasta 1990. La colección más antigua y más numerosa la constituye el cinegiornale Luce. Los noticiarios Luce están divididos en tres series: la serie A (1927-1932), comprende los 1.037 números mudos, exceptuando los 49 primeros, que han desaparecido; la B (1931-1940), que consta de 1.695 números sonoros. Los primeros números de esta serie incluyen rótulos, música y ruidos de sonido directo, pero no comentarios del narrador; por último, la serie C (1940-1945), comprende 478 números sonoros, producidos y difundidos durante la Segunda Guerra Mundial.

Esta investigación se ha centrado en el análisis de los noticiarios Luce producidos entre 1940 y 1945, con el fin de determinar el modo de representación de la Segunda Guerra Mundial en un noticiario que era la base de la propaganda fascista. Para ello, ha sido de gran ayuda la forma en la que está catalogado el material en el archivo Luce. Existe, por un lado, la ficha técnica, que contiene todos los datos relativos a fechas, títulos, producción y dirección; datos éstos que se han obtenido del visionado de los documentos, de los catálogos en papel, así como de otras fuentes externas como la prensa. Por otro lado, la ficha semántica que contiene el resumen o abstract de cada noticia, una descripción de las imágenes y un campo de descriptores formado por un thesaurus que contiene nombres, eventos y lugares presentes en los documentos audiovisuales. Después de la selección de noticias relacionadas con la Segunda 
Guerra Mundial - un total de cuatrocientas setenta y ocho - se procedió al visionado y análisis de las mismas desde el punto de vista del contenido y de la forma, teniendo en cuenta estudios y metodologías precedentes para el análisis de la imagen, que van desde la antropología a la historia social del arte (Cfr. Furió, 2000; Gómez Alonso, 2000).

Para completar este estudio, se ha acudido a otras fuentes primarias como son los documentos consultados en el Archivio Generale dello Stato y el Archivio Paolucci de Calboli . En éstos se han consultado documentos relacionados con los medios de comunicación y la propaganda del Régimen, especialmente lo relativo a la imposición de consignas y notas de servicio dictadas por el Ministerio de Cultura Popular (Minculpop). Naturalmente se ha prestado especial dedicación a los documentos relacionados con el Istituto Luce y con su noticiario.

\section{TRAYECTORIA HISTÓRICA DE LOS NOTICIARIOS CINEMATOGRÁFICOS LUCE}

El noticiario Luce representa un gran valor por sí mismo, porque fue uno de los medios cinematográficos más importantes utilizado por Mussolini para difundir la propaganda oficial del régimen fascista. Su importancia radica precisamente en eso, en la gran difusión de la que gozaba: por una parte, los noticiarios cinematográficos Luce eran obligatorios en todo el territorio nacional; por otra, poseía el monopolio de la información audiovisual. En los primeros años del fascismo se produjo el paso hacia la dictadura a través de una serie de leyes que impedían derechos fundamentales como la libertad de expresión. El 10 de julio de 1924 un decreto-ley abolía la libertà di stampa, lo que suponía que los medios de comunicación de masas estaban controlados o dependían del Régimen.

La influencia que el noticiario cinematográfico podía tener sobre las masas era algo que un periodista como Mussolini podía intuir, sobre todo cuando el índice de analfabetismo entre la población italiana era tan alto en los años veinte. Ante un público sin cultura, un instrumento propagandístico como el cinegiornale Luce ofrecía muchas posibilidades. La información cinematográfica llegaba a todos los públicos y su influencia era presumiblemente mayor que la de la prensa escrita. Todos eran capaces de entender lo que se mostraba en la pantalla: las noticias filmadas eran más bien emocionales, por lo que no se exigía razonar o explicar las cosas. Los sentimientos se evocan a través de recursos como el montaje y la música. El contexto en el que se produce el visionado ayuda a conseguir este efecto: una sala oscura, imágenes de gran tamaño, música que subraya la intensidad de las imágenes... Por ello, cabe presumir una influencia amplia e intensa en los espectadores. Hay que tener en cuenta además que el espectador de entonces era mucho más ingenuo en materia audiovisual, por lo que no se cuestionaba lo que veía. El cine de no ficción además tiene anexa una gran credibilidad que va unida al género y al lenguaje utilizado.

Luce era el primer noticiario cinematográfico de producción italiana. Hasta entonces el mercado de la información cinematográfica en Italia estaba en manos de las compañías francesas y americanas. Nació en 1924 sobre las estructuras de una pe- 
queña empresa privada, el Sindacato Istruzione Cinematografica, fundada pocos meses antes por el periodista Luciano De Feo, especialista en economía. De Feo consideraba que una Italia donde la economía estaba pasando de agrícola a industrial, y pretendía conquistar los mercados internacionales, necesitaba trabajadores cada vez más especializados que controlasen y conociesen las novedades tecnológicas. "Allá donde la vieja escuela es inadecuada, puede tener un espacio el cine, al que no hay que considerar sólo como la diversión del sábado por la noche” (Laura, 2000: 11). Luciano De Feo se dio cuenta de que en Italia existían las condiciones necesarias para dar vida a una producción sistemática de películas con fines educativos: "la empresa, pensaba De Feo, había tenido una buena acogida entre los numerosos organismos públicos o semipúblicos (y privados) que debían advertir la exigencia inmediata de formas modernas de instrucción profesional” (Laura, 2000: 15). Así nació el Sindacato Istruzione Cinematografica (S.I.C.), como sociedad anónima, con sede en un modesto local del romano Lungotevere Castello.

El despegue de esta pequeña productora no fue fácil. De hecho, De Feo intentó involucrar en el proyecto a jerarcas fascistas, para obtener ayudas económicas. Para el Régimen lo que resultaba interesante del medio cinematográfico no era sólo la función didáctica, sino que podía contribuir a la consolidación del consenso: "tal vez no propaganda política de verdad, sino ilustraciones, documentación visual -que llegara a todos los italianos e incluso al extranjero- de las acciones que llevaba a cabo el gobierno" (Laura, 2000: 18).

De Feo realizó varios documentales en los que el Duce era protagonista con el fin de atraer la atención de Mussolini. Además, cambió el nombre a la productora: la SIC pasó a ser L.U.C.E. (L’Unione Cinematografica Educativa). Aunque continuó siendo una sociedad anónima, se invitó a una serie de organismos públicos a repartirse las acciones y a entrar en el consejo de administración.

El bautizo oficial de la nueva productora fue en noviembre de 1924, cuando en una noche de gala en el teatro Augusto (hoy cine Adriano) de Roma se proyectó ante más de cinco mil invitados Aethiopia, el filme de Civinini y Martini producido por Luce sobre la campaña italiana en África.

El nacimiento de Luce marcó un cambio radical en el panorama del cine mundial: por primera vez un estado no comunista (los únicos precedentes se encuentran en la Hungría de Bèla Khun y en la URSS de Lenin) nacía una sociedad estatal para la producción cinematográfica. El evento era significativo para Italia, y no sólo para el cine italiano, porque suponía el primer paso de la intervención directa del Estado en la economía a través de la creación de una empresa industrial.

En julio de 1925, el Consejo de Ministros declaró que utilizaría Luce como "su organización técnica con fines educativos, de instrucción y de propaganda”. Luce, con sus primeros documentales de ciencia, técnica y cultura, constituyó una especie de universidad popular dirigida a los analfabetos, y capaz de llegar, con sus "cinemobili”, a las aldeas más recónditas, donde el cine no había llegado todavía (Laura, 2000). 
También se convirtió en seguida en un potente instrumento de propaganda: el Giornale Luce, que nació en 1927, se proyectaba, como se ha señalado, obligatoriamente en todos los cines del país. Después del noticiario cinematográfico, nació ENIC (Ente Nazionale Industrie Cinematografiche), la primera distribuidora de propiedad pública.

Con la caída del fascismo, comenzaron las dificultades para Luce, que tendría que pagar las culpas de su padrone. Después del 25 de abril de 1945, el noticiario Luce se recicló en las pantallas con el nombre de Nuova Luce. Sin embargo, seguía recordando demasiado al fascismo, por lo que terminaría por desaparecer en 1946. La historia del Istituto Luce, de la posguerra en adelante, en cuanto feudo gubernativo, dependerá del sesgo de la política nacional: habrá ministros que creerán en la función pública, de apoyo al cine italiano y otros que intentarán liquidarlo.

En 1962 Luce se transformó en una sociedad anónima, pero con capital estatal. Entonces fue cuando empezó a valorarse el patrimonio cinematográfico que se encuentra en manos del Istituto Luce. Por ello se creó el Archivo Foto-Cinematográfico Luce, un fondo documental de gran interés para el mundo académico y cinematográfico.

Esta breve trayectoria histórica pone de manifiesto la importancia del cine de no ficción como fuente histórica. Los noticiarios cinematográficos no sólo muestran una sociedad y unos determinados hechos históricos, sino que además permiten ver las ideologías y mentalidades dominantes en un país.

\section{LUCE EN GUERRA}

Italia entró en la Segunda Guerra Mundial el 10 de junio de 1940. La reacción de la población ante la noticia no fue de júbilo y exaltación: la opinión pública era contraria a la guerra y, sobre todo, a estar en el bando de los alemanes. Mussolini tuvo que hacer uso de uno de sus mejores aliados - la propaganda cinematográfica - para convencer al pueblo italiano de la conveniencia de entrar en el conflicto y de la amistad de la nación germana. Además de introducir el tema bélico en el cine de ficción, el régimen fascista intentó cambiar la opinión pública a través del noticiario cinematográfico oficial: el Cinegiornale Luce.

Cuando estalló la Segunda Guerra Mundial, en septiembre de 1939, Italia se mantuvo neutral. Fueron meses de diplomacia, pactos y acercamiento hacia ambas posiciones. Mussolini, que había inculcado a los italianos los valores de la guerra, tuvo que justificar la no intervención a través de los medios de comunicación. La consigna era clara: ofrecer una imagen negativa de la situación bélica. Mussolini temía el efecto que este cambio en la línea política del Régimen podía tener sobre la población: "Los italianos - dijo Mussolini a Ciano - después de haber escuchado durante dieciocho años mi propaganda guerrera, no entienden cómo yo, ahora que Europa está en llamas, pueda convertirme en el heraldo de la paz" (Ciano, 2000: 358).

Para evitar esta confusión en la población, el noticiario Luce trató la Segunda Guerra Mundial de modo esporádico, y sin prestarle la atención que un evento de esas características inicialmente se merecía. Se prefería que el público se distrajera con 
noticias banales como las llamadas "Vistas americanas" o "Instantáneas de América". Se trataba de un repertorio de noticias en las que se revivía la fábula de Cenicienta (Giornale Luce C0005) o en las que modernas amazonas disputaban una carrera de caballos marinos en una piscina californiana, mientras el narrador de Luce señalaba que "uno de los peligros que las participantes más temen es, como en las carreras automovilísticas, los pinchazos, pero por suerte, en el agua no se encuentran clavos" (Giornale Luce C0006, 1940).

Se llenaba así el espacio informativo de Luce y la mente de los espectadores. Dos cuestiones básicas, en esos momentos era necesario silenciar: una, no tratar el tema de la posición subalterna de Italia en la política internacional; y la otra, la escasa preparación militar y económica de Italia a la hora de afrontar la guerra (Rinaldi, 1995: 19).

Era necesario, por tanto, defender la neutralidad de Italia. Aunque la mayor parte de la población estuviera de acuerdo con la no intervención, el noticiario Luce presentaba una serie de motivos que justificaban esta postura, entre ellos, el dolor y la destrucción que genera la guerra entre la población de los países involucrados. En algunas noticias sobre Londres, París y Bruselas, se presentaba la guerra como un hecho doloroso que generaba sufrimiento moral y material (Rinaldi, 1995:35).

No obstante, y a pesar de esta declarada neutralidad, el noticiario puso en evidencia el apoyo italiano a la política expansionista alemana. La información cinematográfica ofrecida a los italianos consideraba la agresión a Polonia como un simple restablecimiento de las relaciones de fuerza establecidas en Versailles, y por lo tanto, un episodio que involucraba solamente a Alemania. Así, la intervención sobre Polonia se calificaba de legítima y defensiva (Rinaldi; 1995: 20).

En los primeros meses de 1940, la posición del gobierno italiano respecto a la guerra cambió, como se ha mencionado: Mussolini quería intervenir. La estrategia de la propaganda se adaptó a las nuevas necesidades políticas: en los meses anteriores a junio de 1940, el noticiario Luce comenzó a presentar la guerra con la intención de persuadir a los espectadores sobre la necesidad de entrar en ella.

Pero la mayor parte de la población era contraria a la intervención, entre otros motivos, porque todavía estaba vivo el recuerdo doloroso de la Gran Guerra y los sufrimientos padecidos entonces. A pesar de la propaganda, muchos italianos eran conscientes de la falta de preparación de las Fuerzas armadas. "No se tiene ni siquiera confianza - señalaba un comisario de Rovigo en un informe del 30 de diciembre de 1939 - en que el Ejército italiano, salido de dos guerras de desgaste (...) pueda haber recuperado su máximo potencial, hasta el punto de estar listo para cualquier intervención” (Colarizi, 2000: 307).

Este rechazo de la población hacia la intervención en la guerra obligó al noticiario a tratar el tema con especial cuidado, sin crear alarmismos y sobre todo, persuadiendo de las ventajas del nuevo giro político para el interés del país. Luce debía demostrar a la población que Italia estaba preparada para entrar en la guerra. Así, a partir de enero de 1940, se editaron numerosas noticias sobre la preparación militar del país: maniobras, adiestramiento y desfiles cuyo objetivo era crear ilusiones en los espectadores sobre los medios técnicos con los que contaba el Ejército. 
Según la representación audiovisual de Luce, la guerra, para la que se preparan los italianos, era una especie de fiesta colmada de desfiles y maniobras. Las imágenes de Luce sobre la Real Academia de Infantería y Caballería de Módena, y la Real Escuela de Aplicaciones de Parma muestran a militares que hacen gimnasia, practican esgrima, se ejercitan con las armas y con los tanques, para "adecuar el propio físico a la fatiga y el propio espíritu al coraje” (Giornale Luce B1687, 1940).

Se insistía en la rapidez de los acontecimientos bélicos y en la victoria segura. La misma realidad lo corroboraba: el fulminante avance alemán en Francia, impresionó a la población italiana, que empezaba a convencerse de la rápida y segura victoria de Hitler. El noticiario Luce contribuyó a crear este estado de opinión con la difusión de noticias sobre las victorias alemanas. Los responsables de la propaganda fascista intuyeron que sólo la perspectiva de una guerra victoriosa y fácil - gracias a la energía y a los medios del aliado nazi - podía ser aceptada por la población. Así, por ejemplo, el 14 de mayo de 1940, un periodista señalaba que "los éxitos alemanes han hecho reflexionar a mucha gente (...). Ninguno duda de que la acción italianoalemana conducirá a la victoria” (Colarizi, 2000: 337).

Por este motivo, Luce presentaba al público la promesa de una guerra relámpago, sin dolor ni sufrimiento, con la que el Régimen pudiese culminar sus aspiraciones territoriales. El objetivo era que aumentase el entusiasmo entre la población por la futura victoria y, sobre todo, que las preocupaciones no fueran excesivas. Para ello, se insistía en el aspecto militar: era necesario demostrar que Italia era una potencia bélica y que tenía a su lado al más potente de los aliados - la Alemania de Hitler.

La representación que se ofrecía de la guerra en los primeros meses cambió totalmente. La destrucción y la muerte fueron sustituidas por la alegría y los triunfos. El conflicto bélico se convirtió en una sucesión de fiestas, desfiles y celebraciones de las victorias. Los noticiarios Luce contribuyeron de este modo a cambiar la opinión de los italianos sobre el conflicto: de una guerra temida en 1939, a una guerra breve, de victoria cercana y segura, en junio de 1940 (Rinaldi; 2000: 11).

Esta falsa visión de la guerra que presentaba el noticiario se mantuvo a lo largo de toda su duración. Como el mismo Ministro de Exteriores reconoció, aunque los recursos fueran escasos y el Ejército no estuviera preparado, Luce debía difundir una imagen idílica de la guerra: sin muertos y con victorias.

Pero la imagen de la guerra en el noticiario experimentó cambios en función del desarrollo bélico. La Segunda Guerra Mundial produjo en Italia una situación particular a partir de 1943: la caída de Mussolini, el armisticio de Badoglio y la creación de la República Social Italiana (RSI), dividieron a Italia en dos zonas. Estos acontecimientos tuvieron su reflejo en el noticiario Luce.

Desde el inicio de la guerra hasta el 25 de julio de 1943 - día en el que el rey destituyó a Mussolini y nombró a Pietro Badoglio jefe del gobierno - se realizaron 318 ediciones de Luce. Estuvieron marcadas por las directrices propagandísticas del Régimen y por la exaltación del fascismo y de sus victorias bélicas. El Ministerio de Cultura Popular (Minculpop) estableció la imagen oficial de la guerra. Ya durante el período de no beligerancia italiano, el ministro competente, había iniciado las reuniones diarias con los representantes de la prensa y otros medios para difundir comuni- 
cados relacionados con el tipo de noticia que había que difundir, así como con las características de la imagen de la guerra que se pretendía mostrar. Aunque Italia se mantenía neutral, la entrada en el conflicto era inminente. Por ello, desde febrero de 1940, el ministro Pavolini impuso a la prensa una serie de consignas por las que debían publicar "semana a semana, fotografías de carácter militar”. Las fotografías, así como las noticias filmadas, mostraban el potencial bélico italiano. Los temas más difundidos eran las maniobras y desfiles militares. Según una disposición de marzo de 1940, estas imágenes "debían exaltar más los medios que los hombres, puesto que el fin supremo era mostrar al pueblo italiano que está bien armado” (Pavolini, 1940). Había que documentar la existencia de buenos cañones, ametralladoras y armas. Las imágenes debían mostrar, según la Disposición del 9 de marzo de 1940, "nuestra raza armada en su expresión de fiereza, valor y juventud” (Mignemi, 1995: 67).

Diez días después de la entrada en la guerra de Italia, el Minculpop reconfirmó el monopolio del Istituto Luce como imagen oficial en el campo de la información fotográfica. Se envió a todos los periódicos la siguiente disposición (20 de junio de 1940): "a partir de mañana, Luce enviará un amplio material fotográfico sobre la guerra. Se ruega publicarlo, sobre todo en este momento en el que las noticias son muy escasas y por razones reservadas lo serán durante algunos días”. (Mignemi, 1995: 68).

Como se establecía en la disposición del 8 julio 1940, "todos los artículos y las fotografías de carácter militar, aunque no fueran enviados por los corresponsales de guerra, debían someterse a la aprobación del Ministero della Cultura Popolare"(Matteini, 1945: 264). De esta manera, a través de la censura, se ofrecía una imagen positiva de la guerra, basada en las victorias nacionales y la potencia militar italiana.

La realidad era bien distinta: aunque algunos sectores de la población estuvieran a favor de la intervención, la mayor parte de la gente veía con recelo la entrada en la guerra, y sobre todo al aliado alemán. Las condiciones de vida y las consecuencias directas de la guerra sobre la población contribuyeron a reforzar este sentimiento antibelicista.

El primer noticiario Luce sobre la guerra - un número único dedicado al 10 de junio del año XVIII de la Era Fascista (1940) - presenta una serie de panorámicas a derecha e izquierda, siempre con la misma angulación, que recogen la masa de gente reunida en Piazza Venezia para escuchar el discurso de Mussolini sobre la intervención italiana en guerra. Estos planos se alternan, de modo milimétrico, con los planos medios contrapicados del Duce en el balcón de Palazzo Venezia. Es significativo el hecho de que los operadores cinematográficos documentaran la voluntad belicista de los italianos registrando una manifestación totalmente orquestada por el Régimen y para nada espontánea (Rinaldi, 2000: 132-133).

En este noticiario se mostraba el entusiasmo popular por la guerra en la ciudad de Roma. En su discurso, Mussolini interpelaba a la masa allí presente: "pueblo italiano, corre a las armas y demuestra tu tenacidad, tu coraje y tu valor". La respuesta del pueblo era siempre "sí". Pero este supuesto entusiasmo popular de los romanos por la guerra no tenía correspondencia en el norte del país. En las ciudades industriales del 
norte, donde la influencia de la máquina fascista era menor, donde se daba una desmitificación de los fastos imperiales-romano-fascistas, la onda pro-intervención fue mucho más reducida, y se circunscribió a determinadas categorías sociales (Colarizi, 1976: 437-438). Incluso algunas imágenes de Luce, sobre todo los primeros planos de la población, ponían de manifiesto una realidad muy distinta a la romana: un sentimiento de angustia, de incertidumbre, de miedo, acompañaban a algunos rostros de mujeres, hombres, incluso soldados. Detrás de estas expresiones se escondía la preocupación por la escasa preparación de Italia para la guerra (Bernagozzi, 1983: 197).

La visión de la guerra ofrecida por Luce, además de positiva, era muy militar. Interesaba seguir las noticias del frente, el desarrollo de la guerra en los distintos escenarios bélicos. Para ello, el Istituto Luce organizó la infraestructura necesaria para registrar imágenes en los distintos frentes de batalla. El director, Benedetto Croce, repitió el tipo de esquema organizativo llevado a cabo por Luce en la guerra de Etiopía. Aumentó, sin embargo, la colaboración entre los órganos cinematográficos del Ejército y el Istituto Luce. En 1940 se creó en el Ejército de Tierra, la Marina y la Aeronáutica, un servicio cinematográfico de guerra formado por operadores y fotógrafos de Luce y personal del servicio fotocinematográfico del Estado Mayor. El Ejército de Tierra contaba con siete unidades que se encargaban de los servicios de comunicación, y otra, para la grabación sonora. La Marina tenía otra unidad formada por siete operadores y cuatro fotógrafos. Las divisiones aeronáuticas contaban con cuatro unidades de reporteros, mientras que en Libia, subordinados al gobernador local, operaban los corresponsales de Luce en la zona (Cerchio, 1940).

El material que se registraba se enviaba a Roma, donde, expertos militares lo visionaban, valoraban y censuraban. Separaban las escenas reservadas a los archivos militares y aquellas utilizadas para la propaganda. Controlaban, además, el montaje final de las imágenes (Argentieri, 1979: 160).

En el primer año de guerra, se produjeron 103 números del noticiario Luce. Se tiraron 10.552 copias que se distribuyeron en todos los cines de Italia y parte del extranjero. En este primer año de guerra, la cobertura realizada por Luce tuvo muchas deficiencias, además de ser bastante superficial. La intención fundamental de la propaganda era evitar la preocupación entre la población, como se ha dicho, de ahí que se exaltaran las victorias y se evitaran las derrotas o los aspectos más negativos del enfrentamiento como los bombardeos. Durante el primer año de guerra, y aunque la población civil estuviera viviendo en primera personal los ataques aéreos británicos, Luce evitaba el tema. Es mucho mayor el número de noticias sobre ataques aéreos italianos - se inauguró una sección dentro del noticiario denominada “Alas italianas”, sobre la aeronáutica nacional y sus triunfos -, que sobre bombardeos aliados.

Para conseguir este efecto propagandístico sobre el espectador, Luce llevó a cabo distintas estrategias. En primer lugar, intentó evitar el tema de la guerra y rellenar el noticiario con informaciones banales ya mencionadas que hicieran olvidar al público la realidad del conflicto. Con excepción de los noticiarios del primer mes de guerra y de los noticiarios de junio de 1941, aniversario de la entrada en la guerra, en los que el conflicto ocupaba la mayor parte del tiempo del noticiario, las noticias que trataban 
directamente la guerra en curso eran escasas: en un noticiario que contenía entre seis y ocho noticias, sólo había entre una y tres noticias sobre el conflicto.

Además, en otros noticiarios se alternaban noticias sobre el desarrollo del enfrentamiento con noticias diversas que conferían un tono jovial al noticiario . En todos los noticiarios del primer año de guerra había siempre una noticia de escaso interés informativo cuyo objetivo era calmar los ánimos y distraer al público. A las "Instantáneas Americanas" se unían otras noticias sobre países europeos - algunos en guerra -, en los que se llevaban a cabo concursos de peluqueros, se jugaba al ajedrez sobre el hielo o se presentaba a la abuela más joven de Italia.

Este tipo de noticias eran más frecuentes en verano o en el período natalicio: había que crear una sensación de normalidad. Así, en el primer verano de guerra, el noticiario Luce insistió en que la gente seguía yendo a la playa como cada año; o en Navidad, los pesebres y las fiestas inundaban la pantalla, junto a la banalidad de noticias como los dentistas para perros o el excepcional jugador de damas de doce años. No faltaban, sin embargo, las noticias que hacían propaganda de las medidas del Régimen a favor de la población - Premios de Natalidad, regalos a los niños y a los soldados, etc. -, ni tampoco los homenajes de cada año, con parafernalia incluida: aniversario de la Marcha sobre Roma, Giornata della Madre e del Fanciullo, el aniversario de las sanciones, etc . Mussolini seguía teniendo un protagonismo absoluto: inauguraciones de obras públicas y visitas a los soldados heridos ocupaban todo su tiempo. También reuniones con el Führer y homenajes públicos: noticias cuyo objetivo, más que tratar sobre la guerra, era exaltar al Duce.

También fue muy constante la atención del noticiario Luce hacia el deporte para crear una ilusión de tranquila cotidianidad. Durante el primer año de guerra, por ejemplo, numerosos acontecimientos deportivos- algunos tan banales como la natación en una piscina sueca - son recogidos por las cámaras de Luce. En invierno, varios noticiarios siguen el desarrollo de los campeonatos nacionales de esquí, y en verano, los concursos de saltos desde trampolín en Roma.

El tono banal impregnaba incluso las noticias sobre la guerra: se daba prioridad a los aspectos marginales del conflicto y no al desarrollo militar del mismo, así como sus consecuencias. Se explicaba a los espectadores cómo funcionaba el servicio aéreo fotográfico de la aviación alemana, o cómo las naves de guerra alemanas se dedicaban a pescar en el Mar del Norte.

Se evitaban especialmente los aspectos más sangrientos y duros del conflicto, como las escenas de batalla. Los soldados nunca estaban en el frente, sino descansando, divirtiéndose o haciendo maniobras. Aunque había heridos, éstos estaban siempre bien atendidos en los hospitales militares, y nunca faltaba la visita del Duce (Giornale Luce C0055, 1940). El noticiario del Régimen insistía en los cuidados que se ofrecía a los soldados, y en las actividades impulsadas por el fascismo a favor de sus combatientes, muchas de ellas protagonizadas por mujeres.

El análisis cuantitativo de las ediciones estrenadas en los primeros meses del conflicto demuestra que Luce insistía en la preparación del Ejército italiano, así como en el potencial armamentístico del aliado alemán. Por una parte, se hacía propaganda de los medios con los que contaba el Eje, y las posibilidades que éstos ofrecían de 
llevar a cabo ofensivas en distintos frentes. Por otra, se interesaba por el desarrollo de la guerra allí donde se encontraba el Ejército italiano: Frente Africano, Frente Occidental, y más tarde, Frente Oriental - Grecia y Yugoslavia.

Las acciones que presentaba Luce del Ejército italiano eran siempre victoriosas: hasta la desastrosa campaña de Grecia constituyó en sus ediciones un gran triunfo italiano. Hay noticiarios que están compuestos sólo por informaciones sobre triunfos italianos. Las victorias alemanas también eran de Italia, y el noticiario Luce insistía en ellas. Esto contribuyó a crear un opinión más positiva del aliado alemán.

El objetivo de esta estrategia informativa, basada en la reiteración de las victorias del Eje, era convencer a los espectadores que el conflicto sería breve y la victoria segura. De hecho, un mes más tarde de la entrada en guerra de Italia, Luce anunciaba la rendición francesa como una victoria italiana.

Para que este tipo de noticias tuvieran una mayor repercusión sobre el público, se colocaban en un lugar privilegiado dentro del noticiario, de manera que su recuerdo fuera más duradero. En este sentido, la estructura más reiterada era la que sigue un orden jerárquico basado en la importancia de la noticia: las últimas eran las más importantes. Pero no siempre era así: en ocasiones, las informaciones más destacadas abrían el noticiario. Por lo tanto, las primeras y las últimas noticias solían incluir temas positivos sobre la guerra y, también, más propagandísticos. En otras ocasiones, la estructura variaba y se alternaban noticias curiosas con otras de mayor relieve sobre el conflicto -, con lo que se conseguía un efecto de banalización de la guerra: se restaba importancia a la gravedad de la situación, creando un efecto anestésico en el público.

Este mismo efecto se pretendía conseguir al tratar aspectos relacionados con la vida cotidiana como la falta de alimentos y materias primas. En este caso, el noticiario incluía regularmente una serie de informaciones sobre la producción de las industrias italianas de guerra o la riqueza del país en alimentos y energía. Se reforzaba la idea de la importancia de la autarquía, en la que las mujeres tenían un papel de relieve.

Este modelo de información sobre la guerra que caracterizaba el noticiario Luce durante el primer año de enfrentamiento, apenas sufrió variaciones en los años sucesivos. Hasta la caída del Régimen, se pretendió evitar la realidad. Con el empeoramiento de la situación interna y el desarrollo de la guerra en los frentes, el noticiario Luce se esforzó aún más en maquillar la realidad. De la exaltación de las victorias italianas, se pasa a la estrategia del descrédito del enemigo: la destrucción era consecuencia de la barbarie del enemigo. Se instaba a la población a resistir y a seguir luchando. Pero la mayor parte de los italianos quería que la guerra acabase, independientemente incluso de quién la venciera. Esto ponía de manifiesto la separación entre la percepción de la realidad de la población y la ofrecida por Luce en las pantallas.

Como consecuencia de la grave situación, el rey Vittorio Emanuele III, en el Gran Consejo del Fascismo, destituyó a Mussolini, y nombró al General Badoglio nuevo jefe de Gobierno. En los cuarenta y cinco días del gobierno Badoglio se produjeron siete noticiarios Luce. Después de dos semanas de interrupción, el noticiario Luce volvió a las pantallas el 5 de agosto de 1943: la numeración comenzó desde cero y 
cualquier elemento o símbolo fascista fue eliminado. Eran signos externos que pretendían dar idea a los espectadores del inicio de una nueva etapa.

La línea editorial de los noticiarios de este periodo se caracterizó por la ambigüedad. Se eliminó cualquier referencia al fascismo y a su líder - ni siquiera para criticarlo -, así como a los acontecimientos acaecidos. Pero tampoco se hablaba de antifascismo: el vocablo "antifascista" no es del estilo de los narradores de Luce (Bernagozzi, 1983: 242). Tampoco hay informaciones sobre el nuevo gobierno, ni sobre las manifestaciones populares por la caída del fascismo. En los tres primeros noticiarios sólo se entiende la caída del fascismo por referencias indirectas tales como el cambio de nombre a una nave acorazada.

Las crónicas sobre la guerra seguían presentando el mismo estilo. Las informaciones sobre los bombardeos aumentaban y se evidenciaba más la destrucción. Se preferían las crónicas sobre la vida civil: "Cómo las mujeres sustituyen a los hombres en sus puestos de trabajo"; "La vacuna contra las enfermedades del ganado ovino"; "El mensaje del Papa al mundo"; "El campeonato de aeromodelismo en Florencia”; etc. La única noticia de gran interés informativo, sobre todo para el desarrollo de la guerra, fue la retirada de las tropas italianas de Sicilia.

El noticiario Luce badogliano presenta dos aspectos característicos. Por un lado, el aumento de noticias sobre bombardeos anglo-americanos y sobre derrotas del Ejército italiano. Éstas no tenían el propósito de crear un resentimiento de la población hacia los aliados, sino de mostrar a los italianos que la suerte del conflicto estaba decidida. Por otro, desaparecieron las simpatías hacia los alemanes (Argentieri, 1979: 185). Aun así, en general, era una información evasiva e incompleta (Laura, 2000: 215).

Después de este paréntesis, y en los primeros días de 1943, Giuseppe Croce, director general del Istituto Luce, decidió el traslado de la empresa y de sus empleados a Venecia, donde se puso en pie el llamado Cinevillaggio:

Todavía éramos jóvenes - declaraba el ex-organizador Lello Bongiovanni - y sólo una minoría de nosotros creía en el fascismo. Quien tenía mujer y una familia que acudir se quedó en Roma. Nosotros que éramos solteros, partimos y casi todos nos casamos en Venecia. La paga era muy golosa: a los más cualificados, 10.000 liras mensuales, 5.000-5.500 liras a los técnicos de segunda categoría. La vida era cómoda, dentro de lo posible, y no era un trabajo duro. El número de empleados de Luce se redujo más o menos a un centenar de personas que se alojaban en pensiones y hoteles. El trabajo de operadores lo hicieron ex-mozos de almacén, fotógrafos o algún corresponsal de la zona (Argentieri, 1979: 189).

Los equipos cinematográficos esenciales, como cámaras, moviolas y luces, no faltaban, pero sí la película virgen. Tampoco había en Venecia un laboratorio para el revelado y positivado de la película impresionada, por lo que, durante meses, se tuvo que mandar el material a un pequeño laboratorio de Turín, con el riesgo de que los camiones fueran asaltados por grupos de partisanos. Además, la Italia de Saló, aunque tenía un gobierno fascista, estaba bajo las órdenes del Ejército alemán. Por este motivo, Luce se vio obligado a pedir a las autoridades alemanas medios de transporte suficientes, pero sus peticiones no obtuvieron demasiado éxito. 
Como continuación de la línea editorial fascista, el noticiario producido en Venecia volvió a las pantallas con la antigua numeración. Esta negación de la realidad se manifiesta en el noticiario Luce de Saló: no hay referencias a la situación de Italia, ni tampoco al desarrollo real de la guerra. La tragedia que el 8 de septiembre supuso para Italia se silenció en Luce. Tampoco hay referencias al regreso de Mussolini. La liberación de Mussolini en Gran Sasso fue captada en exclusiva por las cámaras del noticiario de la UFA. En el noticiario italiano no se incluyó ninguna referencia.

De nuevo, Luce prefería noticias anodinas, hechos irrelevantes: un desfile en Bulgaria con el rey Boris y el pequeño rey Simeón; una ceremonia militar en Rumania, con la presencia del rey Michele y Antonescu; la siega del trigo en Finlandia; un hospital para caballos convalecientes en Alemania; pastos de los valles suizos; vuelos de palomas mensajeras; la fiesta de la Virgen del Carmen en España (Argentieri, 2000: 197).

Hasta la segunda mitad de agosto de 1944, a este tipo de noticias curiosas y de escasa relevancia informativa, se unían las noticias sobre deporte: fútbol, atletismo, patinaje artístico. Cualquier deporte que hiciera olvidar la dura realidad. Noticias cuyo objetivo primordial era evadir al público. Junto a este tipo de noticias, se sucedieron las informaciones sobre homenajes y festividades fascistas. Fueron numerosas las noticias sobre el aniversario de las sanciones por la guerra de Etiopía, sobre los mutilados y caídos por la guerra, y otras que recordaban las "formidables cosas realizadas por el fascismo" y que "un día fueron destruidas por el complot antiitaliano" (Argentieri, 2000: 196).

También se hacía propaganda militar: se exaltaban las virtudes del Ejército de Saló. La imagen que se ofrecía era la de un ejército preparado y vencedor. Las noticias seguían el patrón habitual en estos casos: marchas de la Guardia Nazionale Republicana y de los Bersaglieri, maniobras, el juramento de un batallón del ejército, reclutamiento de paracaidistas, voluntarios de la Marina, la escuela para oficiales, los pilotos de la Aeronáutica. En esta propaganda militarista de Saló, se repetía incesantemente que "la guerra es sagrada y que las armas son la luz para vengar vergüenzas del pasado" (Bernagozzi, 1983: 297).

Aunque en este tipo de noticias las imágenes ponían de manifiesto la precaria situación del Ejército italiano de Saló - soldados sin apenas armas, sin ningún medio acorazado -, el narrador de Luce comentaba las imágenes con gran exaltación:

Paso seguro, músculos de acero, finalmente ha renacido nuestro Ejército; ágil, potente y seguro. Aquí vemos a nuestra Patria todavía capaz de reunir, después del ultraje y la desesperación, nuevas armas, nuevos corazones, nuevas esperanzas". Según Luce, "la gran primavera de la Patria es inminente (Giornale Luce C0386, 1944).

A los italianos, Luce les contaba que el país había recuperado sus Fuerzas Armadas y que éstas estaban listas para echar al invasor americano del suelo patrio. Sin embargo, la credibilidad del noticiario había disminuido mucho en estos últimos años, hasta el punto que en algunos cines, el público saboteaba la proyección: en salas de la 
periferia de Roma como Garbatella o La Marmora, durante la proyección del noticiario Luce, se producían hostilidades hacia el Régimen que obligaron a interrumpir el espectáculo (Argentieri, 1979: 297).

El número 438 sería la última edición de Luce: los 54 números producidos durante la RSI trataron de ofrecer una imagen de normalidad y evitar cualquier referencia a la previsible derrota. Mientras tanto, algunos trabajadores de Luce como Francesco Pasinetti, entraban en contacto con miembros del Comité de Liberación Nacional (CLN) para evitar que el material de los archivos de Luce fuera destruido ("Il cinema repubblichino”, 1979: 69). Los alemanes, por su parte, querían confiscar todo el material de Luce, sobre todo los aparatos cinematográficos. Sin embargo, los encargados de Luce en Venecia lograron evitarlo y salvaron así la maquinaria que se utilizaría para realizar los noticiarios de la democracia. El 26 de julio de 1946 salía a la luz del noticiario Luce Nuova del Istituto Nazionale Luce Nuova. El tema principal del primer número fue la reconstrucción de Italia.

\section{CONCLUSIONES: LO VISIBLE Y LO INVISIBLE}

El noticiario Luce fue uno de los principales instrumentos de la propaganda fascista durante la guerra. Su visión de la contienda resulta sesgada, consecuencia de las directrices del MinCulPop a los medios de comunicación. En sus noticias, se esconden o minimizan los aspectos negativos para exagerar las victorias. Se silencia todo aquello que no conviene al Régimen de Mussolini: desde las derrotas hasta la falta de recursos militares o el hambre de la población civil. Todo esto, para intentar conseguir, de manera más o menos eficaz, el apoyo de opinión pública italiana y para tratar de evitar que el espectador pensara en la dura realidad de la guerra.

El seguimiento que Luce hace de la guerra es bastante deficiente: faltan grandes acontecimientos, como el armisticio del 8 septiembre o la creación de la RSI, como se ha explicado. Tampoco hay referencias al avance aliado en territorio italiano, ni mucho menos a la lucha de la Resistencia o la ocupación alemana. En casi ningún noticiario de los tres periodos señalados hay referencias a la Resistencia. La estrategia de Luce hacia el fenómeno de la Resistencia fue el silencio. Se omitieron los asesinatos por parte de los partisanos de jerarcas fascistas, los atentados contra nazi-fascistas. Noticias que, sin embargo, sí tenían eco en prensa y radio, eran eludidas por el noticiario Luce. Ni siquiera hay referencias al funeral de uno de los protagonistas del fascismo, Giovanni Gentile, ajusticiado por partisanos de los Gruppi di Azione Patriottica (GAP) de Florencia.

A través de la prensa y la radio, y en manifiestos sobre los muros, los fascistas llevaban a cabo una campaña contra los "saboteadores". Luce, sin embargo, prefería callar, tal vez porque consideraban que, al tratar en la pantalla este tema, se le daba más relevancia de la que ellos querían que tuviera: habrían conferido más peso a la oposición armada al fascismo republicano (Argentieri, 1979: 193).

Hay sólo tres noticias en las que hay referencias a la "caza” del partisano por parte de los nazi-fascistas. En dos, soldados italianos junto a alemanes descubren los "nidos” de los partisanos de Eslovenia. En otra, las SS italianas llevan a cabo acciones 
busca y captura de partisanos en territorio nacional. Después de disparos cruzados, los fascistas capturan a dos partisanos. A través de primeros planos, Luce capta el miedo en los rostros de estos miembros de la Resistencia. Al no conservarse el sonido de la noticia, no se puede saber el tratamiento que el narrador de Luce da a estas imágenes. Aun así, la idea que expresan las imágenes es de una rotunda victoria de fascistas sobre los partisanos.

Si las referencias al movimiento partisano son escasas, la participación femenina en el mismo es inexistente. Tampoco hay imágenes o referencias a estas mujeres en los descartes del noticiario, recogidos por el Archivo Luce dentro de su "Repertorio", es decir, fragmentos de noticiario no montados por distintos motivos, desde la mala calidad de las imágenes, la censura o el exceso de material para una noticia. Muchas de las imágenes descartadas son de mujeres de los Fasci Femminili o bien del Servizio Ausialiario Femminile (SAF)de la República de Saló. No se encuentra motivo aparente para su descarte, si no es el exceso de material. Imágenes tomadas desde otras perspectivas que se eliminan del montaje final por ser repetitivas. Hay algunas imágenes de cadáveres de mujeres entre las ruinas, víctimas de bombardeos aliados. La eliminación de este tipo de imágenes responde a una intención de evitar imágenes que pudieran ser exclusivamente impactantes para el público, como mujeres y niños muertos.

Pero las mujeres no sólo participaron en la Resistencia: la Segunda Guerra Mundial supuso un cambio radical en la vida cotidiana de las italianas, que tuvieron que adaptarse a los nuevos tiempos desempeñando nuevos roles sociales hasta el momento asignados a los hombres. Desde la ocupación de los puestos de trabajo abandonados por la población masculina llamada a filas, hasta la participación como personal sanitario en hospitales de guerra dentro de los servicios de asistencia a los heridos o como voluntarias dentro de la sección femenina del Ejército de la República de Saló, la llamada SAF.

Estas facetas de la guerra apenas tienen presencia en el noticiario fascista, que prefiere presentar los aspectos militares de la guerra o la banalidad de algunas situaciones o personajes, como se ha señalado. Estas ausencias intencionadas en las pantallas de Luce resultan de gran interés, ya que se niega se niega la realidad, en detrimento de una imagen de la guerra muy alejada de la vivida por los italianos en los duros años de la contienda.

\section{BIBLIOGRAFÍA}

ARGENTIERI, Mino: L'occhio del regime. Informazione e propaganda nel cinema del fascismo, Florencia,Vallecchi, 1979.

BERNAGOZZI, Giampaolo: Il mito dell'immagine. L’immagine del mito, Bolonia, Editrice Clueb, 1983.

CERCHIO, Fernando: Servizio di guerra, en Cinema, n. 97, 10 de julio de 1940.

CIANO, Galeazzo: Diario 1937-1943, Milán, Biblioteca Universale Rizzoli, 2000.

COLARIZI, S.: L' opinione degli italiani sotto il regime, 1929-1943, Roma, Laterza, 2000. 
COLARIZI, Simona: L’Italia antifascista dal 1922 al 1940: la lotta dei protagonisti, vol. II, Laterza, Bari, 1976.

"Il cinema repubblichino", en Cinemasessanta, Biblioteca "Umberto Barbaro", Roma, 1976.

LAURA, Ernesto G.: Le stagioni dell'aquila. Storia dell'Istituto Luce, Roma, Ente dello Spettacolo, 2000.

MATTEINI, Claudio (Ed.): Ordini alla stampa: la politica interna ed estera del regime fascista nelle disposizioni emanate ai giornali dal ministero della cultura popolare, Roma, Editrice Polilibraria Italiana, 1945.

MIGNEMI, Adolfo: L'Italia s'è desta. Propaganda politica e mezzi di comunicazione di massa fra fascismo e democrazia, Turín, Gruppo Abele, 1995.

PIERSANTI, Andrea, Rinasce all'Istituto Luce la fabbrica del documentario italiano (http://www.imgpress.com/notizia.asp?idnotizia=2846\&idsezione=4), Consulta: 17 de agosto de 2015.

RINALDI, Silvia: I cinegiornali Luce e la non belligeranza. En Argentieri, Mino (Ed.): Schermi di guerra. Cinema italiano 1939-1945, Roma, Bulzoni Editore, 1995. 